\title{
What motivates Jordanians to adopt mobile commerce? An empirical study of the most relevant factors
}

\author{
Mahmud Alkailani $^{a^{*}}$ and Nawras Nusairat ${ }^{b}$
}

${ }^{a}$ Associate Professor of Digital Marketing, Yarmouk University, Jordan

${ }^{b}$ Associate Professor of Marketing and Consumer Behavior, Applied Science Private University, Jordan

\section{CH R O N I C E A B S T R A T}

Article history:

Received: July 22, 2021

Received in revised format: Sep-

tember 16, 2021

Accepted: December 8, 2021

Available online: December 9,

2021

Keywords:

Mobile commerce

e-business

Jordan

Consumer behavior

\begin{abstract}
This study aims to empirically investigate the most influential factors that affect the adoption of Mobile commerce (m-commerce). in Jordan. The factors explored in this study are: Perceived Risk (PR), Perceived enjoyment (PE), perceived ease of use (PEOU), relative advantage (RA), and social Influence (SI). A conceptual framework was proposed to show relationships between variables. Data was collected using surveys collected from 358 participants. Hypotheses were tested using a Structural Equation Modeling [SEM] and the results showed that all independent variables being investigated had significant effects on users' intention to adopt mobile commerce in Jordan. Based on the research findings, several recommendations and implications were reported for academics and companies. Suggestions for future research were also provided.
\end{abstract}

C 2022 by the authors; licensee Growing Science, Canada.

\section{Introduction}

E-commerce, through its 3 waves of evolution, utilized the internet to connect with users (Schnieder, 2016). Nowadays, there are more than 3 billion internet users around the world (Internet Stat World, 2017). In Jordan there are 6 million internet users most of them are very active internet users (Alkailani, 2016). Moving from the era of personal computers in the 1980s to the era of the internet in the 1990s, Mobile commerce (m-commerce). emerged as a new medium of Information technology dissemination that changed the shape and power of electronic commerce (Qingfei et al., 2008). Nowadays, there are more than 4 billion phone subscribers around the world (Internet Stat World, 2017). In Jordan the number reaches 6 million cell phone users of a country with a population of 10 million (Alkailani, 2016). After overcoming most of the challenges mcommerce faced during the first and second waves of electronic commerce evolution, m-commerce became widely accepted and accessed throughout the world (CHNIEDER, 2016; Qingfei et al., 2008). M-commerce covers any transaction utilized via mobile networks and any applications downloaded and used via mobile devices (Qingfei et al., 2008; Khalifa et al., 2002). Mobile commerce showed a very high penetration rate of $60 \%$ and above in some countries (Suki \& Suki,2011; Khalifa, \& Cheung, 2002). Nowadays, users use their mobile phones to search for information, make purchases and conduct financial transactions (Persand \& Azhar, 2012; Hillman \& Neusteadter, 2017; Ali et al., 2019). The emergence of the 3G and 4G technologies helped businesses better design their mobile applications to help users access and share information remotely and stay connected in a very creative way (Wei et al., 2008; Chong, 2012; Khalifa et al., 2012; Husand-yeh, 2018). Mobile applications cover advertising, shopping, banking and managing everyday important activities ( Forg \& woy,2015). Although the potential of m-commerce for businesses is increasing in the western world (Wei et al., 2008), m-commerce in Jordan is still at its first steps. Several studies attempted to investigate the factors influencing the intention to adopt m-commerce in the Arab world (Tarhini et al., 2019). and very limited research was conducted in Jordan.

* Corresponding author.

E-mail address: mkailani@yu.edu.jo (M. Alkailani)

(C) 2022 by the authors; licensee Growing Science, Canada. doi: $10.5267 /$ j.ijdns.2021.12.005 
The aim of this study is to fill an existing research gap in the field of m-commerce adoption by adding a piece of knowledge to the library of literature by establishing a model that could explain the adoption of m-commerce in Jordan.

This research paper will start by exploring the literature on different theories, models, and factors affecting the adoption of m-commerce across the world. Next, a research model will be developed, and a research design is established. Finally, research findings will be listed, analyzed, and recommendations and implications will be discussed.

\section{Literature review}

\subsection{Theoretical framework and research model}

Understanding the motives behind the adoption of information technology (IT) in general and the acceptance of new innovations in particular has been recognized since the 1960s. Theories such as Diffusion of Innovation (DOI) (Rogers, 1962), Theory of Reasoned Actions (TRA) (Fishbein \& Ajzan,1975), Theory of Planned Behavior (TPB) (Taylor \&Todd,1995), and the Unified Theory of Acceptance and Use of Technology (UTAUT) (Vankatessh et al., 2012) are all contributions to the understanding of individuals' intentional behavior to do or accept new innovations.

It is well known that Innovations in information technology have led to the emergence of mobile commerce that, to be successful, needs to be accepted by users.

This study adopts constructs related to the acceptance of technology in addition to other constructs researchers believe have a predicted influence on Jordanian users of m-commerce. Perceived Risk [PR], Social Influence [SI], Perceived Ease of Use [PEOU], Perceived Enjoyment [PE], and Perceived Usefulness [PU] will be integrated in an empirical model that will help understand the underlying motives that push Jordanians to adopt m-commerce.

\subsection{Mobile commerce (m-commerce)}

M- commerce has been defined in different ways at different points of time. It was defined as buying and selling products and services using cell phones and other personal digital devices. Similarly, Venkatesh et al. (2002) see m-commerce as an enhanced type of e-commerce using cell phones and personal digital assistants (PDAs). Akter and Wamba (2016) also consider m-commerce an extension of the electronic commerce system. Kaplan (2012) sees m-commerce as any activity which is carried out through mobile networks connected by personal mobile devices. Kowfe (2019) sees it as users' ability to buy products and services anywhere with the help of wireless-internet supported devices. This will, in return, help create an economic value utilizing e-commerce infrastructure (Cozzarin \& Dimitrovic, 2017). M- business and m-commerce are used interchangeably and represent an integral part of conducting transactions among individuals and businesses using wireless telecommunication networks (Zhang et al., 2012). M-commerce became important and accessible since mobile users can access the internet at any time wherever they are with no limits (Ali et al., 2019). This has opened opportunities to businesses, and increased transactions among individuals and businesses (Ghazali et al., 2019; Lee \& Wons, 2017). This adoption of mobile devices has grown rapidly across the world with an obvious contribution of telecommunication infrastructure; specially the emergence of the $3 \mathrm{G}$ And $4 \mathrm{G}$ technologies that enabled users to access and share information at any time at a high speed (Chong et al., 2012; Zhang et al., 2012; Hillman \& Neusteadter, 2016). M-commerce is promising and expected to boost in the coming future due to the proliferation of smartphones and devices, personalization of products and services, and the everyday enhanced technology infrastructure such as the coming 5G technology (Bhatti, 2007). Despite the promising nature of $\mathrm{m}$-commerce across the world, sales through $\mathrm{m}$-commerce are still representing a very small portion of total sales generated using e-business systems ( $\mathrm{Lu}, 2012)$. Therefore, researchers currently focus on the understanding of the factors that affect the acceptance of $\mathrm{m}$-commerce and the continuous influence of those factors to maintain continuous intention (Lu, 2012; Hsu \& Yeh, 2018; Kowfe, 2019; Bhullar \& Gill, 2018, 2019).

\subsection{M-commerce Adoption}

The state of research of $\mathrm{m}$-commerce adoption around the world is evolving since the emergence of smart phones (Single et al., 2017). Different theories and models tried to investigate the factors that affect technology acceptance. Theories such as Diffusion of Innovation [DOI] (Rogers, 1962), Theory of Reasoned Actions [TRA] (Fishbein \& Ajzan, 1975), Theory of Planned Behavior [TPB] (Taylor \&Todd, 1995), and the Unified Theory of Acceptance and Use of Technology [UTAUT] (Vankatessh et al., 2012) are all examples. Diffusion of innovation [DOI] was firstly introduced by Rogers (1995) and was first to investigate the factors that lead consumers to accept new technology. Rogers (1995) believes that relative advantage [RA], Compatibility, Complexity, Trialability and Observability represent important aspects of any new technology. Technology Acceptance Model [TAM] was introduced by Davis (1989) and proposed several factors that can predict behavior intention to use new technology. Davis (1989) proposed perceived usefulness [PU] and Perceived ease of use [PEOU] as major determinants influencing the acceptance of new technology. One limitation of TAM is that it ignores the effect of cultural differences on the process of technology acceptance (Tarhini et al., 2019). Theory of planned behavior [TPB] introduced by Ajzen (1991), and Ajzen and Fishbein (1980) and was initially derived from theory of reasoned action [TRA] introduced by Fishbein and Ajzen (1975). It focused on social and personal factors by introducing subjective norms [SN] and 
attitudes as determinants of behavioral intention to use technology [IU]. Unified theory of acceptance and use of technology [UTAUT] was introduced by Vankatesh (2003). The theory proposed performance expectancy [PE], effort expectancy [EE], social influence $[\mathrm{SI}]$ and facilitating conditions $[\mathrm{FC}]$ as major factors affecting the acceptance and use of new technology. In 2003 a new theory [UTAUT2] was expanded by adding new constructs; hedonic motivation [HM], Habit, and Price Value [PV] as determinants of technology acceptance.

We believe that some of the constructs from the above discussed theories and models are interrelated or overlapped and could measure the same dimension. Subjective Norms [SN], for example, is defined as "a person's perception that most people who are important to him/her think he/she should/not perform the behavior on question" (Fishbein \& Ajzen, 1975). This construct is far like social influence [SI] which is defined as ".... And an individual's beliefs, attitude, behavior, and opinion are affected by others" (Vankatesh et al., 2012).

In the same token, Complexity is defined as “... the degree to which an innovation is perceived as being relatively difficult to understand and use" (Rogers, 1983). which is similar to Perceived ease of use [PEOU] introduced by Rogers (1995). and refers to "the degree to which an individual believes that using new technology would be free of physical and mental effort, and the degree of complexity will not become an inhibitor that discourages that adoption of innovation" (Rogers,1995). Relative advantage [RA] is defined as "the degree to which innovation is perceived as being better than the idea it supersedes" (Rogers, 1983). Giving the same meaning, perceived usefulness [PU] which is defined as "the prospective user's subjective probability that using a specific application system will increase his/her performance", could indicate the same dimension. Based on the above discussion of theories and models in the context of innovation acceptance and use, this research will investigate the influence of the following variables on the acceptance and adoption of m-commerce in Jordan: Perceived Usefulness [PU], Perceived Ease of Use [PEOU], Perceived Enjoyment [PE], Social Influence [SI], and Perceived Risk [PR].

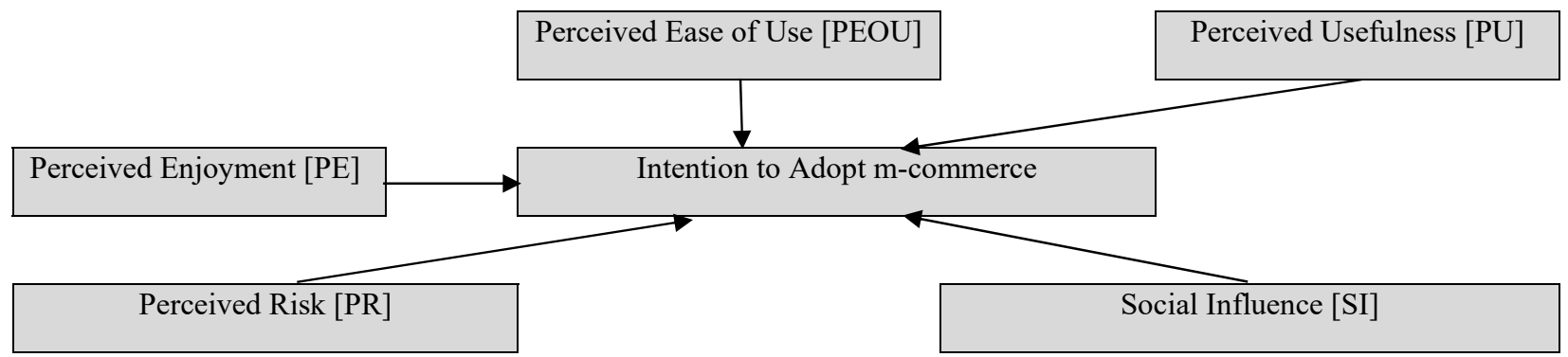

Fig 1: The Proposed model

The research model shown in Fig. 1 identifies 5 major factors, researchers believe are of the most influence on the adoption on m-commerce in Jordan. While developing the model, researchers relied on different models and theories, discussed earlier, such as Theory of Diffusion of Innovation (DOI)(Rogers,1962), Theory of Reasoned Actions (TRA) (Fishbein \& Ajzan, 1975), Theory of Planned Behavior (TPB) (Taylor \&Todd,1995), and the Unified Theory of Acceptance and Use of Technology (UTAUT) (Vankatessh et.al, 2012). Each variable is discussed and described followed by hypotheses proposed to describe relationships.

\subsection{Perceived usefulness (PU)}

Davis et al. (1989) defined PU as “the prospective user's subjective probability that using a specific application will increase a person's job performance". Several studies (Suki \& Suki, 2011; Alkailani et al., 2012) found that PU has an important influence on usage behavior. Similarly, Lee and Wong (2016) believe that the usage of new technology is pushed by how useful it will be. Davis (1989) also believes that the tendency to use specific technology will increase when users see technology as beneficial. Thus, it creates value to users in different new ways (Dai \& Palvia, 2009; Bhullar \& Gill, 2018; Chi, 2018). Based on these literature facts, the following hypothesis is proposed:

Hypothesis 1: There is a statistical relationship between the degree of PU of m-commerce and the tendency of users to adopt it.

\subsection{Perceived Ease of Use (PEOU)}

PEOU is defined as "the degree to which a person believes that using a particular system would be free of effort" (Davis, 1989). Several studies found that users of new technology are more willing to use it when it entails less uncertainty (Erikson \& Shames, 2003; Alkailani et al., 2012), easy to use (Chen \& Lin, 2014; Abu Shanab et al., 2010), free of extra effort (Agrebi \& Jallais, 2015) and un-complex and easy to learn (Marinkovic \& Kalinic, 2017). The following hypothesis is proposed:

Hypothesis 2: There is a statistical relationship between PEOU of $m$-commerce and the tendency of m-commerce users to adopt it. 
PE can be defined as the intrinsic reward derived from the use of the technology. Research found that enjoyment has an impact on users' attitudes toward using technology (Agrebi \& Jallais, 2015; Marinkovic \& Kalinic, 2017) and that technology is more accepted when it is fun and pleasant (Pandey \& Chala, 2018). Yet, users are more willing to adopt enjoyable technology compared to non-enjoyable technology (Suki \& Suki, 2011; Chou et al., 2019).

Chung and Hwang (2018) found that enjoyable users' experience when using technology has a possible impact on their continuous technology usage behavior. Additionally, Agrebi and Jallias (2015) argue that PE positively affects users' evaluation of $\mathrm{m}$-commerce products and services. The following hypothesis is proposed:

Hypothesis 3: There is a statistical relationship between the degree of enjoyment of $m$-commerce and the tendency of users to adopt m-commerce.

\subsection{Social Influence (SI)}

Social Influence (SI) was firstly introduced by Kelman (1958) and rooted in social influence theory. SI is defined as "an individual's belief about whether significant others think that one should engage in the activity" (Lu et al., 2003). Several researchers found that SI has an impact on m-commerce acceptance (Kalifa \& Cheng, 2005; Chang, 2005; Vankatesh et al., 2012; Lewis \& Palmer, 2015). Influence from primary groups, for example, such as friends and family members have a direct impact on users' adoption of m-commerce (3, Chong et al., 2012; Lin \& Lu, 2015) and represent a major player of m-commerce adoption (Wei et al., 2008; Moorthy et al., 2017). Satisfied users of technology usually share their; positive experiences with others through appositive word of mouth (WOM) which encourages new users of technology to adopt it (Alkailani, 2016 b). The following hypothesis is proposed,

Hypothesis 4: There is a statistical relationship between the degree of social influence existing in a society and the tendency of users to adopt m-commerce due to that influence.

\subsection{Perceived Risk (PR)}

PR is defined as "The customer's subjective expectations of suffering a loss in pursuit of a desired outcome” (Alkailani, 2016). PR could be divided into three categories: functional, psychological and financial (Alkailani, $2016 \mathrm{~b}$ ). In the context of the virtual world, Product risk, security risk, and privacy risk are of major concern (Suki \& Suki, 2007). Jordan is a collectivist culture (Collectivism score $=82.2$ ). (Alkailani et al., 2012). Collectivist cultures usually have a high uncertainty avoidance level (Jordan Uncertainty avoidance score= 110). People of such cultures tend to avoid situations with high risk and uncertainty. M-commerce is part of e-commerce where almost all transactions are virtual and entail a certain level of risk; vendors, products and places are virtual and unseen. Thus, PR in online transactions is usually greater than that at traditional stores; known as "Brick and Mortar". People in collectivist cultures would like to see, touch and try products before usage to minimize the risk associated with buying that product (Alkailani, 2016). Most m-commerce applications demand a certain amount of information before allowing users to benefit from these applications (Kim et al., 2008; Kim \& Prabhakar, 2010). Users of mcommerce technology also pay great attention to the level of data security associated with the transaction (Jimenez et al., 2014). The higher the data transmitted are secured, the more the m-commerce application is trusted (Wei et al., 2008). Nowadays, financial information are still the most concerns for m-commerce users (Acquisti, 2004; Salam et al., 1989).

The following hypothesis is proposed:

Hypothesis 5: There is a statistical relationship between the level of perceived risk $m$-commerce users perceive when adopting m-commerce and their willingness to adopt m-commerce applications.

\section{Research Methods}

\subsection{Measures and Questionnaire Design}

A thorough understanding of the relevant literature revealed five key determinants of m-commerce acceptance and adoption including Perceived Ease of Use [PEOU], Perceived Usefulness [PU], Social Influence [SI]; Perceived Risk [PR], and Perceived Enjoyment [PE]. All of the previously indicated variables are assumed to drive individuals' intentions to use Mobile Commerce [IU]. Accordingly, a conceptual model with five exogenous variables (PEOU; PU; SI; PR; and PE). and one endogenous variable (IU). was developed. Previously established measures were adapted to capture the six variables of the conceptual model, presented in (Fig. 1). Twenty-four measurement items in total, assessed on a 5-point Likert scale were employed to estimate the responses of m-commerce users. Perceived ease of use was measured using four indicators (e.g. Mobile commerce applications are usually clear and understandable for me). adapted from (Davis, 1989). relating the simplicity and clarity of m-commerce applications. Perceived usefulness was operationalized using measurement items adapted from (Davis, 1989), describing the value m-commerce applications may add to our lives (e.g. Using Mobile commerce applications always help me carry out my tasks easily). Another four items addressing the influence of social context such as family, colleagues, and community in general were adapted from (Lu,2013). to capture the latent variable "social influence". Perceived risk was observed using four statements relating to psychological tension of using m-commerce applications (e.g. 
mobile commerce applications entail some uncertainty and vulnerability), adapted from (Suki \& Suki, 2007). The measurement of perceived enjoyment was based on (Agrebi \& Jallais, 2014)). scale with its four indicators, addressing the joy and entertainment a user may experience when using m-commerce applications (e.g. I believe that using mobile commerce applications will be very interesting). And lastly, intention to use mobile commerce was assessed using a four-item scale adapted from (Wang \& Li, 2010). The questionnaire was organized into two sections. The first section included the pre-screen question "do you consider yourself as a regular user of m-commerce applications?" and recorded the respondent's demographic profile including age, gender, educational level, and level of income. The second one reported the respondent's perception of the variables under investigation on a scale ranging from 1-strongly disagree to 5-strongly agree. Original questionnaire was translated using back-translating techniques by two bilingual marketing professors. Resulting questionnaire was further subjected to academic and field piloting to ensure validity and reliability of the measures, and the clarity of the questions to respondents.

\subsection{Sampling and Data Collection}

The research population of our study consists of regular individual users of m-commerce applications in Jordan. Data was collected using a convenient sample using a self-administered questionnaire distributed in selected commercial banks, travel agents' selling points, and electronics retail shops in Jordan. The sample consists of individuals who own cell phones and use them in their daily life activities and could be represented as potential prospects for this study. Although the study utilized convenience sampling, the selection of respondents followed a systematic randomization. In sum, 420 questionnaires were handed to respondents, who were willing to participate in the survey. 62 questionnaires were discarded based on a screening question and due to incomplete responses. Therefore, 358 valid and complete questionnaires were retained and considered for data analysis. To ensure good construct validity, most items included in the survey were adopted for previously validated scales use by prior researchers (Wang \& Wu, 2005; Davis, 1989)

\subsection{Data Analysis and Findings}

Utilizing the valid and complete questionnaires, a dataset of 358 was generated. The dataset was inspected first to make sure we have complete and normally distributed data. Descriptive statistics ensure data completeness and validity. The values of skewness and kurtosis for all observed variables were within acceptable range of normal distribution. Fig. 2 presents the sample's demographic profile. Descriptive measures show that (56.7\%). of respondents were females. Most of the respondents were $27-35$ years old (56.7\%). and first-degree holders (56.7\%). Most of them were privately hired (57.8 \%). with an income level ranged between 500-999 (45\%).
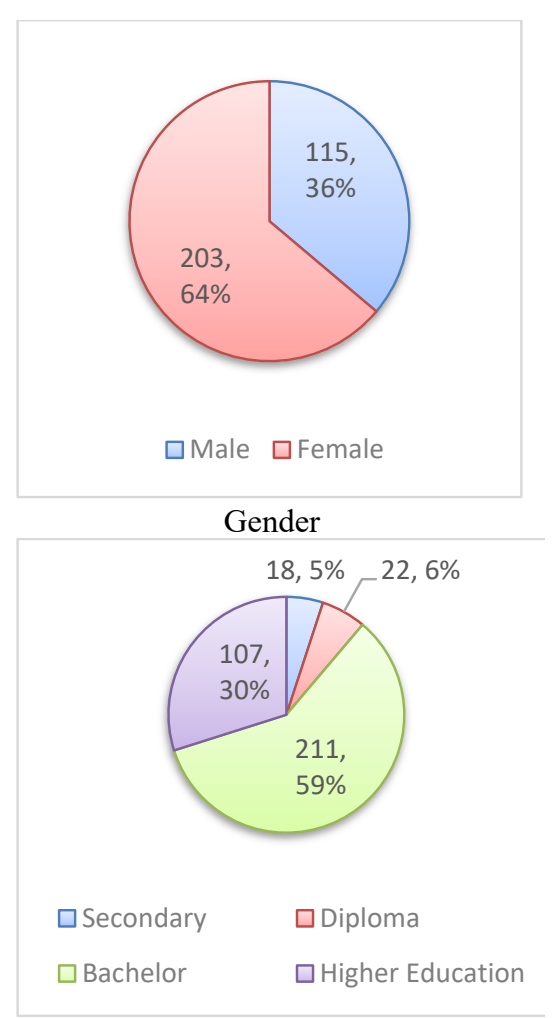

Education

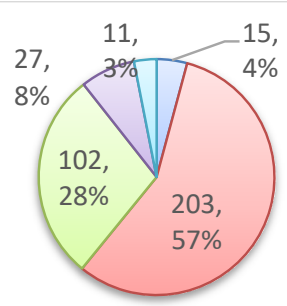

$\square$ 18--26 $\square 27--35 \square 36--44$

$\square 45--53 \square>53$

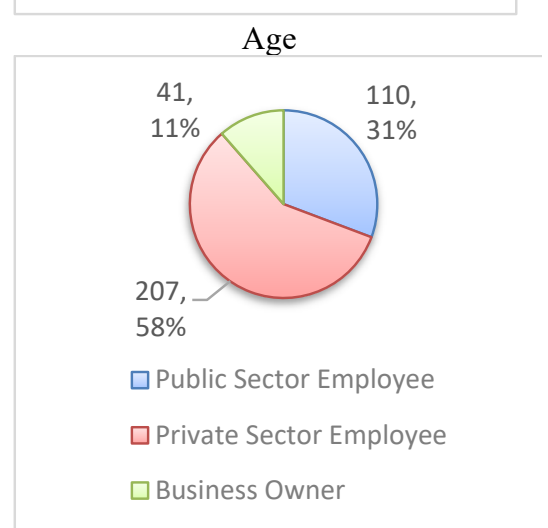

Job

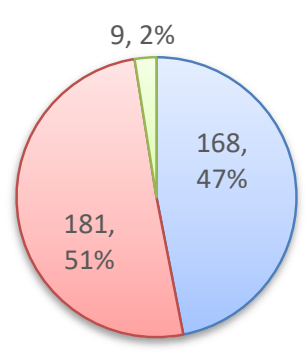

$\square$ Single $\square$ Married $\square$ Other Marital status

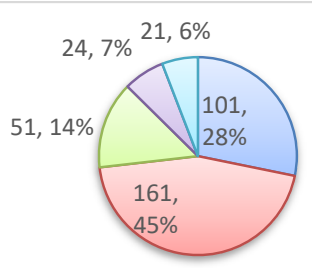

口Less than $500 \mathrm{JDs} \quad$ 口500-999 JDs

口1000-1499 JDs प1500-1999 JDs

$\square 2000$ JDs and above

Income

Fig. 2. Personal characteristics of the participants 


\subsection{Measurement Model}

The measurement model with six latent variables measured by 24 observed variables were assessed using Structural Equation Modeling (SEM). In line with Anderson and Gerbing's (1988). model-building process, the measurement model was developed first. Fit indices of the primary measurement model $(\chi 2 / \mathrm{df} 4.251, \mathrm{RMSEA}=0.056, \mathrm{CFI}=0.94, \mathrm{NFI}=0.93, \mathrm{IFI}=0.94)$. suggested an acceptable level of model fit (Hair et al., 2006).

Confirmatory factor analysis was further used to validate the model. Constructs' validity was concluded based on the measures of convergent and discriminant validity indicators. Factor loadings for all measurement items on their respective latent variables (Table 1). were above the acceptable threshold (0.50). suggested by Hair et al. (2006). Average variance extracted AVE for all of the model's variables as shown in Table 1 were within the recommended cut-off value of $(>50 \%)($ Fornell $\&$ Larcker, 1981).

Table 1

Factor loadings and Construct Validity and Reliability

\begin{tabular}{|c|c|c|c|c|c|}
\hline \multirow{2}{*}{ Variables } & \multirow{2}{*}{ Items } & \multirow{2}{*}{ Factor loadings } & AVE & \multirow{2}{*}{ CR } & \multirow{2}{*}{ Cronbach's alpha } \\
\hline & & & $\%$ & & \\
\hline \multirow{4}{*}{$\begin{array}{l}\text { Perceived Ease of Use } \\
{[\mathrm{PEOU}]}\end{array}$} & PEOU1 & 0.89 & \multirow{4}{*}{0.68} & \multirow{4}{*}{0.93} & \multirow{4}{*}{0.93} \\
\hline & PEOU2 & 0.94 & & & \\
\hline & PEOU3 & 0.94 & & & \\
\hline & PEOU4 & 0.76 & & & \\
\hline Perceived Usefulness & PU1 & 0.85 & \multirow{4}{*}{0.8} & \multirow{4}{*}{0.95} & \multirow{4}{*}{0.96} \\
\hline \multirow[t]{3}{*}[\mathrm{PU}]{} & PU2 & 0.87 & & & \\
\hline & PU3 & 0.91 & & & \\
\hline & PU4 & 0.92 & & & \\
\hline \multirow{4}{*}{$\begin{array}{l}\text { Social Influence } \\
{[\mathrm{SI}]}\end{array}$} & SI1 & 0.81 & \multirow{4}{*}{0.68} & \multirow{4}{*}{0.92} & \multirow{4}{*}{0.93} \\
\hline & SI2 & 0.79 & & & \\
\hline & SI3 & 0.87 & & & \\
\hline & SI4 & 0.88 & & & \\
\hline \multirow{4}{*}{$\begin{array}{l}\text { Perceived Risk } \\
\text { [PR] }\end{array}$} & PR1 & 0.85 & \multirow{4}{*}{0.81} & \multirow{4}{*}{0.97} & \multirow{4}{*}{0.97} \\
\hline & PR2 & 0.84 & & & \\
\hline & PR3 & 0.9 & & & \\
\hline & PR4 & 0.91 & & & \\
\hline \multirow{4}{*}{$\begin{array}{l}\text { Perceived Enjoyment } \\
{[\mathrm{PE}]}\end{array}$} & PE1 & 0.9 & \multirow{4}{*}{0.67} & \multirow{4}{*}{0.93} & \multirow{4}{*}{0.94} \\
\hline & PE2 & 0.92 & & & \\
\hline & PE3 & 0.91 & & & \\
\hline & PE4 & 0.81 & & & \\
\hline \multirow{4}{*}{$\begin{array}{l}\text { Intentions to Use Mobile Commerce } \\
\text { 「IU }\end{array}$} & IU1 & 0.9 & \multirow{4}{*}{0.81} & \multirow{4}{*}{0.97} & \multirow{4}{*}{0.97} \\
\hline & IU2 & 0.89 & & & \\
\hline & IU3 & 0.91 & & & \\
\hline & IU4 & 0.92 & & & \\
\hline
\end{tabular}

Furthermore, inter-correlations among the model's variables (Table 2). and squared correlations among the variables compared to AVE of each one (Table 2). suggested that the variables are sufficiently different from each other (Fornell \& Larcker, 1981). Accordingly, both convergent and discriminant validity of the model's constructs were established.

Table 2

Constructs Inter-correlations

\begin{tabular}{|c|c|c|c|c|c|c|}
\hline Construct & 1 & 2 & 3 & 4 & 5 & 6 \\
\hline 1. Perceived Ease of Use & 1.00 & 0.38 & 0.28 & 0.36 & 0.42 & 0.31 \\
\hline 2. Perceived Usefulness & & 1.00 & 0.33 & 0.31 & 0.45 & 0.29 \\
\hline 3. Social Influence & & & 1.00 & 0.42 & 0.31 & 0.35 \\
\hline 4. Perceived Risk & & & & 1.00 & 0.33 & 0.32 \\
\hline 5. Perceived Enjoyment & & & & & 1.00 & 0.34 \\
\hline 6. Intentions to Use Mobile Commerce & & & & & & 1.00 \\
\hline
\end{tabular}

\section{Table 3}

Discriminant Validity Assessment

\begin{tabular}{|c|c|c|c|c|c|c|}
\hline Construct & 1 & 2 & 3 & 4 & 5 & 6 \\
\hline 1. Perceived Ease of Use & 0.68 & 0.14 & 0.08 & 0.13 & 0.18 & 0.10 \\
\hline 2. Perceived Usefulness & & 0.80 & 0.11 & 0.10 & 0.20 & 0.08 \\
\hline 3. Social Influence & & & 0.68 & 0.18 & 0.10 & 0.12 \\
\hline 4. Perceived Risk & & & & 0.81 & 0.11 & 0.10 \\
\hline 5. Perceived Enjoyment & & & & & 0.67 & 0.12 \\
\hline
\end{tabular}

Note: AVE (Diagonal values). for each variable is greater than squared correlation (off-diagonal values). between respective variables. 
Reliability measures as shown in (table 1). above indicated a good reliability for all constructs with a reliability score greater than the recommended benchmark (0.70). on both Cronbach's reliability and composite reliability (Hair et al., 2011).

\subsection{Findings of Structural model}

Referring to model fit indices reported in Table 4 below, the structural research model exhibited a satisfactory goodness of fit to observed data. All the fit indices were within the recommended cut-off values of model fit (RAMSE $<0.08$, GFI $\geq 0.90$; $\mathrm{CFI} \geq 0.90$; NFI $\geq 0.90$; and IFI $\geq 0.90$ ) (Byrne, 2001; Hair et al., 2006).

Table 4

Structural Model Fit

\begin{tabular}{ccccccc}
\hline Chi sq (df) & Chi sq/df & RMSEA & GFI & CFI & NFI & IFI \\
\hline $51.96^{*}(28)$ & 1.86 & 0.07 & 0.95 & 0.95 & 0.90 & 0.95 \\
\hline
\end{tabular}

$* P$-value $<.01, d f:$ degree of freedom

Path analysis revealed a support to the five structural paths, lending an acceptance to all of the research hypotheses. Specifically, users' intentions to use mobile commerce was found to be significantly affected by perceived usefulness $(\beta=0.26, \mathrm{p}$ $<0.001)$ followed by perceived ease of use $(\beta=0.24, \mathrm{p}<0.001)$. Support was also reported to the impact of perceived risk $(\beta$ $=0.19, \mathrm{p}<0.001)$, perceived enjoyment $(\beta=0.17, \mathrm{p}<0.001)$, and social influence $(\beta=0.08, \mathrm{p}<0.001)$, which played a less significant role in driving users' intentions to use mobile commerce. The findings of hypothesis testing are shown in Table 5.

Table 5

Hypothesis Testing Findings

\begin{tabular}{|c|c|c|c|c|c|c|}
\hline \multicolumn{3}{|c|}{ Path/Hypothesis } & \multirow{2}{*}{$\begin{array}{c}\text { (及) } \\
0.24\end{array}$} & \multirow{2}{*}{$\begin{array}{c}\boldsymbol{P} \\
* *\end{array}$} & \multirow{2}{*}{$\begin{array}{l}\mathbf{C R} \\
5.54\end{array}$} & \multirow{2}{*}{$\begin{array}{c}\text { Result } \\
\text { Supported }\end{array}$} \\
\hline Perceived Ease of Use & $\rightarrow$ & Intentions to Use Mobile Commerce & & & & \\
\hline Perceived Usefulness & $\rightarrow$ & Intentions to Use Mobile Commerce & 0.26 & $* *$ & 7.62 & Supported \\
\hline Social Influence & $\rightarrow$ & Intentions to Use Mobile Commerce & 0.08 & 0.034 & 2.10 & Supported \\
\hline Perceived Risk & $\rightarrow$ & Intentions to Use Mobile Commerce & 0.19 & $* *$ & 5.13 & Supported \\
\hline Perceived Enjoyment & $\rightarrow$ & Intentions to Use Mobile Commerce & 0.17 & 0.002 & 5.99 & Supported \\
\hline
\end{tabular}

\section{Discussion}

This Study aims to investigate the landscape of Mobile commerce and examine the most influencing variables that affect the adoption of mobile commerce in Jordan. To achieve the intended purpose of this study, a model based on theories and models related to technology acceptance and diffusion was constructed and measured. This study adds to the literature of mobile commerce through investigating the intention to adopt mobile commerce in a country not being investigated before; Jordan.

The observed findings significantly verified all the hypotheses being tested in this study. The findings show that Perceived Usefulness [PU], Perceived Ease of Use [PEOU], Social Influence [SI], Perceived Risk [PR] and Perceived Enjoyment [PE] are all determinants of intention to adopt mobile commerce. In line with many studies investigating mobile commerce adoption across the world, PU and PEOU appeared as the most influential variables to predict mobile commerce adoption among Jordanian Users. This result is predicted and in line with many previous research in the context of mobile commerce (Wei et al., 2008; Lu, 2013; Anckar, 2002; Marinkovic \& Kalinic, 2016; Dai \& Palvai, 2009). The more mobile users find m-commerce with more benefits and with fewer complications, the more they will form a positive feeling towards $\mathrm{m}$-commerce which will affect their future adoption of $\mathrm{m}$-commerce applications. This fact is consistent with findings of Dai and Palvia (2009), Ramayah and Ignatius (2005) and Bahatti (2007). Researchers believe that the positive intention to adopt m-commerce in Jordan is since, nowadays Jordanians are computer and English literate and are familiar with m-commerce devices and applications. So, they find m-commerce ease to utilize. It is worth mentioning that m-commerce is not restricted to buying and selling using mobile phones. Activities such as internet browsing, social gaming, mobile banking, education, health care, travel and getting real time information using different applications constitute the essence of m-commerce.

Findings also show that Perceived Risk [PR] exert a significant influence on the adoption of mobile commerce among Jordanian users. PR is highly correlated with uncertainty avoidance [UA] (Alkialni \& Kumar, 2011). Since Jordan is a collectivist culture with high UA score of 110 , it is expected to see Jordanians perceive high level of risk when using mobile commerce. The environment of mobile commerce is of a virtual nature where some level of risk is involved. Risk is usually correlated with trusting the environment where transactions are taken place (Bhullar \& Gill, 2018; Kim \& Prabhakar, 2000). Issues such as privacy and security of information, fraud, and identity theft are of major concerns for mobile commerce users in general. These issues are of more importance to Jordanians because of the special nature of Jordanian culture which is characterized by high-risk avoidance level (Hofstede, 2001). Mobile commerce activities include those applications (for example, Commerce applications and bank applications) that require users to trust the application and the vendor while entail some level of uncertainty. Previous research shows that Jordanians prefer face to face communication over virtual communication and prefer 
to see and touch products before buying to reduce any kind of risk associated with commerce and banking transactions (Alkailani et al., 2012).

Perceived enjoyment (PE) also found to have a major impact on Jordanians' attitude towards adoption of m-commerce. Using mobile technology in general entails some level of enjoyment (Suki \& Suki, 2011), which will develop a positive attitude towards adopting this technology (Agrebi \& Jallais, 2015). Mobile users carry their cell phones at all times to get pleasure oriented information in the form of timely, updated notifications of those areas they are interested in (Pandey \& Chawla, 2018; Lin \& Lu, 2014)). Since Jordanians are active mobile users and participate heavily on social media sites using their cell phones (Alkailani et al., 2012) research results appear to affirm this fact.

This study also finds that Social Influence has an impact on the adoption of m-commerce. This result could be attributed to the fact that nowadays most m-commerce applications have become social. Applications could be categorized in one of the social zones known to researchers in areas of relationship, entertainment, publishing and commerce (Tauten \& Salamon, 2019). Culture and country background affects all areas of information technology (Qingfei et al., 2008). The effect of family, friends and community appeared to have an impact on m-commerce adoption (Lu, 2013; Pandey \& Chawla, 2018). Jordan is a collectivist culture (Hofestede, 2011). where people socialize a lot and care about each other's interests and opinions, thus the social context is of concern to them.

\subsection{Implications, Limitations and future research}

The findings of this study have both academic and practical implications. First, this study has contributed to the m-commerce adoption research literature by investigating the effects of key $\mathrm{m}$-commerce variables. Second, previous studies examined each model and theory and related constructs associated with them individually. This study incorporated variables from different models and theories and group them in one predictive model to check for influence on m-commerce adoption. Third, most previous studies investigated the adoption of $\mathrm{m}$-commerce in the context of western culture, while this study is one of the few studies that tries to explore the effect of these variables in the Middle East; Jordan. Practical implications of the study will help digital business strategists in the area of M-services, M-marketing, M-CRM and M-retailers to develop their future strategies in the area of $\mathrm{m}$-commerce, which is evolving and changing over time, taking into consideration cross cultural differences of $\mathrm{m}$-commerce users. This study offers foreign m-commerce managers who are seeking to invest in the Middle East in general and in Jordan in particular and target customers who have an intention to adopt mobile applications initial information about users' characteristics and attitudes towards this phenomenon. Results from the SEM showed that perceived ease of use and perceived usefulness were the important indicators of Jordanians' intention to adopt m-commerce. So it is recommended that $\mathrm{m}$-commerce application providers should focus on making applications useful and free of extra effort. Mcommerce developers should make the content and applications of great value to users. Perceived risk is an important aspect of building trust and reducing uncertainty when adopting m-commerce applications. M-commerce strategists should adopt means (Example: Advanced encryptions). that makes m-commerce transactions secured and risk-free. Also, m-commerce providers can ensure users that their applications are trusted by registering their applications with trusted security organizations. Reducing risk and building trust with $\mathrm{m}$-commerce users should be a concern to m-commerce application providers.

The result section also showed Perceived enjoyment and social influence. Current research shows that perceived enjoyment and social influence are highly correlated (Tauten \& Salomon, 2019). Researchers suggest that m-commerce developers should make both content and applications sociable and shareable to increase the number of m-commerce users. M-commerce developers should also use different social channels and social opinion leaders to attract m-commerce users to adopt new applications.

As a social science research, this study has limitations. First, this study was conducted in Jordan which will limit its ability to generalize results across the world due to cultural differences. Researchers suggest that future researchers should conduct similar research in other countries to be able to make a comparison of results across cultures. Second, this is a cross-sectional study where researchers investigated the adoption of $\mathrm{m}$-commerce which will limit its ability to trace dynamic changes in $\mathrm{m}$ commerce users' behavior. Researchers suggest that future research be conducted at different time intervals to predict behavior over time. Third, the study investigated only a limited number of variables (PEOU, PU, PR, PE, and SI). Future research is encouraged to include more variables and study their impact on m-commerce adoption and to study the moderating effect of demographics (Gender, Age, etc.) on the m-commerce adoption process. Fourth, the validity of results depends heavily on the sampling technique used in this study. Data was collected from $358 \mathrm{~m}$-commerce users using a convenient sample using a self-administered questionnaire distributed in selected commercial banks, travel agents' selling points, and electronics retail shops in Jordan. Generalizability of results could be limited because of the sampling technique used and the sample size as well.

\section{References}

Abu Shanab, E., Pearson, M., \& Setterstrom, A. (2010). Internet Banking and Customers' Acceptance in Jordan: The unified Model's Perspective. Communications of the Association for Information System, 26(23), 493-524. 
Akter, S., \& Wamba, S. F. (2016). Big data analytics in E-commerce: a systematic review and agenda for future research. Electronic Markets, 26(2), 173-194.

Agrebi, S., \& Jallias, J. (2015). Explain the intention to use smart phones for mobile shopping. Journal of Retailing and Consumer Services, 22, 16-23.

Ajzen, I. (1991). The theory of planned behavior. Organization Behavior and Human Decision Processes, 50(2), 79-211

Ajzen, I, \& Fishbein, M. (1980). Understanding Attitudes and Predicting Social Behavior, Engle wood Cliffs, New Jersey: Prentice Hall

Ali, M., Wali, E., Al-Hinai, Y., \& Kurnia, S. (2019). A process approach to examining mobile commerce adoption Progression. Journal of Systems and Information Technology, 21.

Alkailani, M., Azzam, I., \& Athamneh, A. (2012). Replicating Hofstede in Jordan: Ungeneralized, Reevaluating the Jordanian Culture. International Business Research, 5(4), 71-80.

Alkailani, M., \& Kumar, R. (2011). Investigating Uncertainty Avoidance and Perceived Risk for Impacting Internet buying: A study of three cultures. International Journal of Business and Management, 6(5), 76-92.

Anckar, B. (2002). Adoption drivers and intents in the mobile electronic marketplace: survey findings. Journal of systems and information technology, 6(2).

Bhatti, T. (2007). Exploring factors influencing the adoption of mobile commerce. Journal of Internet Banking and Commerce, 12(3), 1-13.

Bhullar, A., \& Gill, P. (2018). Adoption of Mobile Commerce: An Empirical Study among Mobile Users. International Journal of Engineering Technology Science and Research, 5(5)

Bhullar, A., \& Gill, P. (2019). Future of Mobile Commerce: An Exploratory Study on Factors affecting Mobile Users' Behavior Intention. International Journal of Mathematical, Engineering and Management Sciences, 4(1), 245-258

Byrne, M. (2001). Structural equation modelling with AMOS: Basic concepts, applications, and programming. London: Lawrence Erlbuam Associates

Chen, Y., \& Lan, Y (2014). An Empirical Study of the Factors Affecting Mobile Shopping in Taiwan. International Journal of Technology and Human Interaction, 10(1), 19-30.

Chi, T. (2018). Understanding Chinese consumer adoption of apparel mobile commerce: An extended TAM approach. Journal of Retailing and Consumer Services, 44, 274-284.

Chong, A., Chan, F., \& Ooi, K. (2012). Predicting consumer decisions to adopt mobile commerce: Cross country empirical examination between China and Malaysia. Decision Support Systems, 53, 34-43.

Chong, A. (2013). Mobile commerce usage activities: The roles of demographic and motivation variables. Technological Forecasting and Social Change, 80(7).

Chu, W., \& Lu, H (2007). Factors affecting online purchse intention in Taiwan: an empirical study based on the value-intention framework, Internet Research, 17(2), 139-155.

Chou, D. Li, T., \& Ho, C (2019). Factors influencing the adoption of mobile commerce in Taiwan. International Journal of Mobile Communication, 16(2).

Chung, L., \& Hwang, I. (2018). What Drives Mobile Commerce? Determinants of Behavioral intents to Adopt m-Commerce. The Korean Society for Facility Management, 23(4).

Cozzarin, B., \& Dimitrov, S (2017). Mobile commerce and device specific perceived risk. Electronic Commerce Research, 16(3), 335-354.

Dai, H., \& Palvia, P. (2009). Mobile commerce adoption in China and the United States: A cross- Cultural Study. The data base for advances in Information systems, 40(4). 43- 61

Davis, D., Bagozzi, P., \& Warshaw, R. (1989). User acceptance of computer technology: a comparison of two theoretical models, Management Science, 35, 982-1003.

Davis, D. (1989). Perceived usefulness, perceived ease of use, and user acceptance of information technology, MIS Quarterly, 13, 319-336.

Falk, F., \& Miller, B (1992). A primer for soft modeling. Akron, OH: University of Akron press.

Fishbein, M.A., \& Ajzen, I., (1975). Belief, Intention and Behavior: An introduction to Theory and Research. Addison-Wesley, Reading, Massachusetts.

Foxall, R. (1995). Cognitive Styles of Consumer Initiators. Technovation. 15(5), 269-288.

Fornell, C., \& Larcker, D. F. (1981). Evaluating structural equation models with unobservable variables and measurement error. Journal of Marketing Research, 18(1), 39-50.

Ghazali, E., Mutum, D., Chong, J., \& Nguyen, B. (2018). Do consumers want mobile commerce? A closer look at M-shopping and technology adoption in Malaysia. Asia Pacific Journal of Marketing and Logistics, 30(4), 1064-1086.

Hair, J. F., Black, B., Babin B. Anderson, R. E. \& Tatham, R. L. (2006). Multivariate Data Analysis, $6^{\text {th }}$ ed., Upper Saddle River, New Jersey: Pearson Education Limited.

Hillman, S., \& Neusteadter, C. (2017). Trust and mobile commerce in North America. Computer in Hman behavior, 70, 1021.

Hofstede, G. (2001). Culture's consequences, $2^{\text {nd }}$ ed., Thousand Oaks: Sage publishing.

Hsu, C., \& Yeh, C. (2018). Understanding the critical factors for successful M-commerce adoption. International Journal of Mobile communication, 16(1).

Jimenez, N., Martin, S, Azuela, J. (2014). Trust and satisfaction: the keys to client loyalty in mobile commerce. Academia Revista, 29(4), 486-510. 
Kaplan, A. M. (2012). If you love something, let it go mobile: Mobile marketing and mobile social media 4x4. Business horizons, 55(2), 129-139.

Khalifa, M., Cheng, S. K., \& Shen, K. N. (2012). Adoption of mobile commerce: A confidence model. Journal of computer information Systems, 53(1), 14-22.

Khalifa, M., \& Cheung, S. (2002). Adoption of Mobile commerce: Role of Exposure. Proceeding of the 35th Hawaii International Conference on system sciences

Kim, K., \& Prabhakar, B. (2000). Initial trust, perceived risk, and the adoption of internet banking. International conference on international systems 2000 proceedings, 55

Kim, D., Ferrin, D., \& Rao, H. (2008). A trust-based consumer decision-making model in electronic commerce: The role of trust, perceived risk, and their antecedents. Decision Support Systems. 44(2), 544-564.

Kowfe, M. (2019). Understanding the Factors Influencing Mobile Commerce Adoption by Traders in Developing Countries: Evidence from Ghana. International Working Conference on Transfer and Diffusion of IT.

Lee, W., \& Wong, S. (2016). Determinants of Mobile Commerce Customer Loyalty in Malaysia. Procedia - Social and Behavioral Sciences, 224, 60-67.

Lin, K., \& Lu, H. (2015). Predicting mobile social network acceptance based on mobile value and social influence. Internet Research, 25(1), 107-130.

Lu, J. (2012). Are personal innovativeness and social influence critical to continue with mobile commerce?. Internet research, 24(2), 134-159.

Lee, M., Cheung, M., \& Chen, Z. (2005). Acceptance of Internet-based learning medium: the role of extrinsic and intrinsic motivation. Information and Management, 42, 1095-1104.

Marinkovic, V., \& Kalinic, Z. (2017). Antecedents of customer satisfaction in Mobile commerce: Exploring the effect of customization. Online Information review, 41(2). 138-154.

Pandey, S., \& Chawla, D. (2018). Exploring Factors That Drive Adoption of Various Categories of M-commerce: An Emerging Market Study. Global Business Review, 21(1), 1-21

Qingfei, M., Shobo, J., \& Gang, Q. (2008). Mobile commerce user acceptance study in China: A revised UTAUT Model. Tsinghua Science and Technology, 13(3), 257-264.

Ramayah, T., \& Ignatius, J. (2005). Impact of perceived usefulness, perceived ease of use and perceived enjoyment on intention to shop online. ICFAI Journal of Systems Management (IJSM), 3(3), 36-51.

Salam, A., Rao, Raghav, \& Pegels, C. (1998). An Investigation of Consumer-perceived Risk on Electronic Commerce Transactions: The Role of Institutional Trust and Economic Incentive in a Social Exchange Framework. AMCIS 1998 Proceedings.

Suki, N., \& Suki, N. (2011). Exploring the relationship between perceived usefulness, perceived ease of use, perceived enjoyment, attitude and subscribers' intention towards using $3 \mathrm{G}$ mobile services. Journal of Information technology management, 12(1), 1-7.

Tarhini, A., Alalwan, A., Shammout, A. and Al-Badi, A. (2019). An analysis of the factors affecting mobile commerce adoption in developing countries. Review of International Business and Strategy, 29(3), 157-179.

Taylor, S., \& Todd, P. (1995). Assessing IT usage: The role of prior experience. MIS quarterly, 19(4), 561-570.

Wang, W., \& Li, H. (2010). Factors influencing mobile services adoption: A brand-equity perspective. Internet research, 22(2), 142-179

Wang, S., \& Wu, J. (2005). What drives Mobile commerce? An empirical evaluation of the revised technology acceptance Model. Information \& Management, 42, 719-729

Wei, T., Marthandan, G., Chong, A., Ooi, K., \& Armugam, S. (2008). What drives Malaysian m-commerce Adoption? An Empirical analysis. Industrial management and data, 109(3), 370-388.

Zhang, 1., Zhu j., \& Liu, Q (2012). A meta-analysis of mobile commerce adoption and the moderating effect of culture. Computers in Human Behavior, 28(2012), 1902-1911.

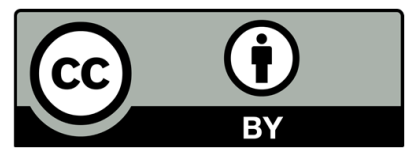

(C) 2022 by the authors; licensee Growing Science, Canada. This is an open access article distributed under the terms and conditions of the Creative Commons Attribution (CC-BY). license (http://creativecommons.org/licenses/by/4.0/). 